\title{
PENGARUH KUALITAS PELAYANAN, KUALITAS PRODUK, KEPERCAYAAN, DAN NILAI NASABAH TERHADAP KEPUASAN NASABAH (Studi pada PD BPR BKK Purbalingga Cabang Bukateja)
}

\author{
Okky Mudinarko \\ Universitas Muhammadiyah Purwokerto \\ Suyoto \\ Universitas Muhammadiyah Purwokerto
}

\begin{abstract}
This study aimed to determine to correlation between four independent variables of quality servive, quality products, trust, and customer value on customer satisfaction variable. This study was explanatory research using quantitative approach of multiple regression. Sample of this study were 103 customers of the bank. Data analysis techniques used in the study were multiple regression analysis, $t$-test, F-test, and classical assumption testing. Data of this study was taken using quistionnaire distributed to customers of the bank and analyzed using SPSS 16 version.The resulf of F-test analysis showed that factor of service quality, product quality, trust and customers value gave effect simultaneously with 52,7\% of the value of Adjusted $R$ Square on customer satisfaction in the bank. In addition, $47,3 \%$ of the remaining value were affectted by other factors which were not discussed in this study. The result of partial t-test showed that service quality gave the biggest effect on customer satisfaction in the bank. The more accessable the bank service was, the more interested people in the bank would be. Marketing strategy showed significant effect in improving service quality. Thus, the better the marketing management in the bank was, the more interested people in the bank would be.
\end{abstract}

Keywords: Service Quality, Product Quality, Trust, Customer Value, and Customer Satisfaction.

\section{ABSTRAK}

Penelitian ini bertujuan untuk mengetahui hubungan antara empat variable bebas dari Kualitas Layanan, KualitasProduk, Kepercayaan, dan Nilai Nasabah terhadap variabel Kepuasan Nasabah. Jenis penelitian yang digunakan dalam penelitian ini adalah penelitian eksplanator idengan menggunakan pendekatan kuantitatif yang digunakan yaitu regresi berganda. Sampel dalam penelitian ini terdiri atas 103 responden yang menjadi nasabah PD. BPR BKK Purbalingga Cabang Bukateja. Teknik analisis data dalam penelitian menggunakan teknik analisis regresi berganda, uji t, uji f dan uji asumsi klasik. Analisis yang digunakan dengan SPSS versi 16 dan questioner sebagai alat pengumpulan data yang dibagikan kepada nasabah BPR BKK Purbalingga.

Hasil analisis dengan menggunakan Uji F menunjukkan faktor KualitasLayanan, KualitasProduk, Kepercayaan, dan NilaiNasabah secara simultan memberikan pengaruh sebesar $52,7 \%$ dari nilaiAdjusted $R$ Square terhadap kepuasan nasabah di PD. BPR BKK Purbalingga Cabang Bukateja, sedangkan sisanya $47,3 \%$ dipengaruhi faktor lain yang tidak diteliti pada penelitian ini. Melalui analisis Uji t secara parsial Kualitas Layanan memberikan pengaruh paling besar terhadap kepuasan nasabah di PD. BPR BKK Purbalingga Cabang Bukateja. Semakin mudah pelayanan yang diberikan Bank maka akan meningkat pula minat orang untuk melakukan transaksi di PD. BPR BKK Purbalingga Cabang Bukateja. Strategi pemasaran sangat perpengaruh penting dalam meningkatkan kualitas layanan maka dari itu semakin baik manajemen pemasaran di PD. BPR BKK Purbalingga Cabang Bukateja maka semakin banyak orang minat untuk menjadi nasabah.

Kata Kunci:Kualitas Layanan, Kualitas Produk, Kepercayaan, Nilai Nasabah, dan Kepuasan I . Pendahuluan Nasabah

Pada zaaman modern ini perkembangan ilmu pengetahuan dan teknologi berdampak pada dunia usaha yang semakin meningkat, baik perusahaan yang bergerak di bidang industri, perdagangan maupun jasa, terlebih pada perusahaan perbankan. Kesuksesan dalam 
persaingan akan dapat dipenuhi apabila perusahaan bisa menciptakan dan mempertahankan nasabah. Dalam arti baru yaitu, memuaskan kebutuhan nasabahdengan strategi pemasaran yang berorientasi pada nasabah, membuat perusahaan harus memahami dan memenuhi baik perilaku maupun kebutuhan nasabah untuk mencapai kepuasan nasabah.

Kepuasan nasabah merupakan perasaan seseorang dari kesenangan atau kekecewaan yang timbul dari apa yang telah diterima membandingkan apa yang dirasakan dalam kaitannya dengan harapann.Dalam perbankan, kepuasan dan ketidakpuasan nasabah adalah hasil penilaian nasabah terhadap apa yang diharapkannya dengan membeli dan menggunakan suatu produk jasa bank. Harapan itu lantas dibandingkan dengan persepsinya terhadap kualitasyang diterimanya dengan menggunakan produk jasa itu.

Kualitas produk adalah totalitas fitur dan karakteristik produk atau jasa yang bergantung pada kemampuannya untuk memuaskan kebutuhan yang dinyatakan atau tersirat (Kotler \& Amstrong, 2008). Herawati dan Prayekti (2011) dalam Pratiwi, Ni Putu Lennydan Seminari, Ni Ketut (2015)mengemukakan bahwa variabel kepercayaan pelanggan berpengaruh positif dan signifikan terhadap kepuasan nasabah.

Kepuasan nasabah ditentukan oleh kualitasproduk dan layanan yang dikehendaki nasabah,sehingga jaminan kualitas menjadi perioritas utamabagi bank. Pelayanan adalah kunci keberhasilan dalam berbagai usaha atau kegiatan yang bersifat jasa. Oleh karena itu menurut Gilaninia et al. (2013), kualitas layanan adalah elemen penting dalam menentukan keberhasilan suatu perusahaan jasa dan salah satu upaya yang dilakukan oleh setiap perusahaan khususnya pada perusahaan yang bergerak di bidang jasa perbankan.

Kualitas pelayanan adalah sebagai upaya pemenuhan kebutuhan dan keinginan nasabah serta ketepatan penyampaiannya dalam mengimbangi harapan nasabah.Pelayanan merupakan tindakan atau perbuatan yang dapat ditawarkan oleh suatu pihak kepada pihak lain yang pada dasarnya bersifat intangible (tidak berwujud fisik) dan tidak menghasilkan sesuatu. Hermawan (2011) mengatakan bahwa tingkat kepercayaan pelanggan dapat diukur melalui beberapa faktor antara lain kejujuran dalam bertransaksi, tanggung jawab perusahaan terhadap pelanggan dan masih banyak lagi. Kepercayaan pelanggan adalah apabila salah satu pihak mempunyai keyakinan dalam keandalan dan integritas partner kerjasama.

\section{TIinjauan Pustaka}

\section{Kualitas Pelayanan}

Ariani (2009:205) menyatakan kualitas pelayanan merupakan atribut global perusahaan dan merupakan pertimbangan pelanggan terhadap keberhasilan atau superioritas perusahaan secara menyeluruh. Menurut Tjiptono dan Fandy (2007) kualitas pelayanan dapat diartikan sebagai upaya pemenuhan kebutuhan dan keinginan konsumen serta ketepatan penyampaiannya dalam mengimbangi harapan konsumen.

\section{Kualitas Produk}

Kualitas produk merupakan kemampuan produk di dalam menjalankan fungsinya dan kualitas produk dapat diukur melalui pendapat konsumen tentang kualitas itu sendiri, sehingga selera pribadi sangat mempengaruhi. Kualitas itu sendiri sering dianggap sebagai ukuran relatif kebaikan suatu produk atau jasa. Nilai subjektivitas dari seseorang menyebabkan adanya perbedaan dalam memberikan pengertian mengenai kualitas (Kresnamurti dan Putri, 2012:3).

\section{Kepercayaan}

Menurut Hermawan(2011), tingkat kepercayaan pelanggan dapat diukur melalui beberapa faktor antara lain kejujuran dalam bertransaksi, tanggung jawab perusahaan terhadap pelanggan dan masih banyak lagi. Kepercayaan pelanggan adalah apabila salah satu pihak mempunyai keyakinan dalam keandalan dan integritas partner kerjasama.

\section{Nilai Nasabah}

Kotler dan Armstrong ( 2012) dalam Iwan (2013) mengemukakan bahwa nilai pelanggan adalah perbandingan pelanggan antara semua keuntungan dan semua biaya yang harus dikeluarkan untuk menerima penawaran yang diberikan. 


\section{Kepuasan Nasabah}

Menurut Kotler dan Keller (2009:138-139) mengemukakan bahwa kepuasan (satisfaction) adalah perasaan senang atau kecewa seseorang yang timbul karena membandingkan kinerjayang dipersepsikan produk atau hasil terhadap ekspetasi mereka. Menurut Kotler (2009) kepuasan pelanggan adalah sejauh mana kinerja yang diberikan oleh sebuah produk sepadan dengan harapan pembeli.

\section{Metode Penelitian}

\section{Populasi dan Sampel}

Menurut Sugiyono (2013), populasi adalah wilayah generalisasi yang terdiri atas objek atau subjek yang mempunyai kualitas dan karakteristik tertentu yang ditetapkan peneliti untuk dipelajari dan kemudian ditarik kesimpulannya. Pada penelitian ini yang menjadi populasi adalah seluruh nasabah PD BPR BKK Purbalingga Cabang Bukateja berdasarkan produk jenis tabungan sebanyak 4.983 nasabah.Menurut Sugiyono (2013), sampel adalah bagian dari populasi yang dimiliki oleh populasi. Bila populasi besar, dan peneliti tidak mungkin mempelajari semua yang ada pada populasi. Oleh karena itu sampel harus betul-betul representatif dalam hal besaran sampel. Pemilihan sampel (responden) menggunakan teknik non probability sampling dengan teknik purposive sample. Dalam teknik ini, penentuan sampel yang dipilih berdasarkan pertimbangan tertuentu (Sugiyono, 2013).

Kriteriapurposive sampling diantaranya:

a. Nasabah PD BPR BKK Purbalingga Cabang Bukatejaberdasarkan produk jenis tabungan yang masih aktif dalam jangka waktu minimal 3 tahun.

b. Bekerja sebagai (Petani, Pedagang, dan PNS/Pegawai).

c. Nasabah yang menabung.

\section{Metode Pengumpulan Data dan Pengukuran Data}

Metode pengumpulan data dilakukan melalui studi pustaka yaitu mempelajari tema yang berhubungan dengan pokok bahasa yang sedang diteliti. Dengan mengkaji buku-buku literatur, jurnal, makalah dan sumber-sumber lain yang berkaitan dengan penelitian untuk memperoleh landasan teoritis secara komprehensif terkait Bank BKK. Penelitian ini menggunakan kuesioner, yaitu alat bantu yang sangat penting dalam kegiatan riset. Daftar pertanyaan atau kuesioner diartikan sebagai suatu daftar tertulis yang berisikan rangkaian pertanyaan

\section{Hipotesis Penelitian}

Hipotesis dalam penelitian ini adalah:

Hipotesis 1: Kualitas Layanan, Kualitas Produk, Kepercayaan dan Nilai Nasabahsecara simultan berpengaruh positif terhadap Kepuasan Nasabah.

Hipotesis2: Kualitas Layanansecara parsial berpengaruh positif terhadap Kepuasan Nasabah.

Hipotesis 3: $\quad$ Kualitas Produksecara parsial berpengaruh positif terhadap Kepuasan Nasabah.

Hipotesis 4: Kepercayaan secara parsial berpengaruh positif terhadap

Hipotesis 5: $\quad$ Kepuasan Nasabah. Kepuasan Nasabah.

\section{Hasil dan Pembahasan}

\section{Deskripsi Responden}

Dalam penelitian ini populasi berjumlah 4.983 nasabah PD. BPR BKK Purbalingga Cabang Bukateja telah dihitung dengan rumus Slovin sehingga menghasilkan sampel minimal 98 nasabah. Metode yang digunakan dalam penelitian ini adalah metode purposive sampling. Untuk mengantisipasi kurangnya data, peneliti membagi 110 kuesioner, dari jumlah tersebut kuesioner yang dijawab dan dikembalikan berjumlah 110, setelah dilakukan pengecekan hanya 103 kuesioner yang dianalisis berdasarkan rumus 
teknik pengampilan sampel yang telah ditentukan, dan 7 kuisoner tidak dianalis. Dengan demikian respon rate kuesioner yang di analisis sebanyak 103.

\section{Karakteristik Responden}

Responden akan dibagi menjadi 4 kategori yaitu : responden menurut jenis kelamin, umur, pendidikan terakhir, pekerjaan, dan lama menjadi nasabah. Tujuan pengkategorikan tersebut untuk mengetahui karakteristik responden, sehingga hasil dari masing - masing kategori dapat diketahui.

Data responden berdasarkan jenis kelamin, menunjukan bahwa nasabah BPR BKK Purbalingga Cabang Bukateja berjenis kelamin laki-laki sebanyak 65 orang $(63,2 \%)$ dan perempuan sebanyak 38 orang $(36,8 \%)$. Hal ini menjelaskan bahwa nasabah BPR BKK Purbalingga Cabang Bukateja didominasi oleh nasabah laki-laki. Hal ini mengindikasikan bahwa laki-laki mempunyai proporsi terbesar yang berdagang dan meninjau kredit pada PD BPR BKK Cabang Bukateja. Klasifikasi umur dikelompokan ke dalam 3 kelompok mulai dari umur 30 tahun sampai diatas 55 tahun. Berdasarkan pengelompokan umur nasabah maka umur $43-55$ tahun sebanyak 67 orang $(65,1 \%)$. Hal ini menunjukan bahwa nasabah PD. BPR BKK Purbalingga Cabang Bukateja lebih banyak didominasi oleh usia 43-55 tahun, pada usia tersebut merupakan usia nasabah yang didominasi oleh kalangan nasabah yang berkerja sebagai petani, pedagang, dan PNS/pegawai karena merupakan target nasabah bagi PD BPR BKK Purbalingga Cabang Bukateja. Mayoritas nasabah berpendidikan sarjana yaitu sebanyak 43 orang $(41,8 \%)$. Hal ini menunjukan bahwa nasabah PD. BPR BKK Purbalingga Cabang Bukateja rata nasabah berpendidikan sebagai sarjana.

Mayoritas nasabah bekerja sebagai pedagang sebanyak 68 orang $(66,1 \%)$. Hal ini mengindikasikan PD BPR BKK Purbalingga Cabang Bukateja rata nasabahnya bekerja sebagai pedagang. Kedepan lebih menekankan konsep pedagang lalu disusul pegawai/PNS dan petani. Mayoritas nasabah di PD BPR BKK Purbalingga Cabang Bukateja sudah menjadi nasabah $\geq 5$ sebanyak 68,9 (71\%). Hal ini mengindikasikan bahwa nasabah PD BPR BKK Purbalingga Cabang Bukateja sudah menjadi nasabah cukup lama, yaitu diatas 5 tahun.

\section{Instrumen Penelitian dan Uji Asumsi Klasik}

Hasil uji validitas menunjukkan bahwa korelasi positif total skor pernyataan pada setiap variabel menunjukkan hasil yang signifikan dengan nilai signifikan kurang dari 0,05 sehingga dapat disimpulkan bahwa setiap variabel memiliki indikator pernyataan yang valid. Hasil uji reliabilitas menunjukkan bahwa variabel kualitas layanan memiliki indeks koefisien reliabilitas yang tinggi yaitu sebesar 0,804; variabel kualitas produk memiliki indeks koefisien reliabilitas yang tinggi yaitu sebesar 0,837; variabel kepercayaan memiliki indeks koefisien reliabilitas yang tinggi yaitu sebesar 0,799; variabel nilai nasabah memiliki indeks koefisien reliabilitas yang tinggi yaitu sebesar 0,815; dan variabel kepuasan nasabah memiliki indeks koefisien reliabilitas yang sangat tinggi sebesar yaitu sebesar 0,740. Sehingga dapat disimpulkan bahwa kuisioner dalam penelitian ini reliabel. Uji Normalitas dilakukan dengan melihat pada bentuk distribusi data melalui analisis grafik, yaitu pada histogram maupun normal probability plot (Ghozali, 2013). Uji multikolinearitas suatu model regresi dikatakan bebas multikolinearitas apabila mempunyai VIF $<10$ dan mempunyai angka tolerance $>0,1$. Uji heteroskedastisitas dilakukan dengan metode glejser, yaitu dengan meregresikan variabel bebas terhadap nilai absolut residualnya, data dinyatakan terbebas dari asumsi heteroskedastisitas apabila hasil regresi menunjukan nilai signifikansi $>\alpha(0,05)$.

\section{Analisis Data}

\section{a. Regresi Linear Berganda}

Uji regresi linear berganda bertujuan untuk mengetahui seberapa besar pengaruh variabel independen terhadap variabel dependen yaitu pengaruh variabel Kualitas Pelayanan (X1), Kualitas Produk (X2), Kepercayaan Nasabah (X3), dan Nilai Nasabah (X4) terhadap Kepuasan Nasabah (Y). Hasil dari persamaan regresi linear berganda dapat dilihat dalam tabel 4.16 sebagai berikut ini (Ghozali, 2013): 
Tabel 4.1 Hasil Uji Regresi Linear Berganda Coefficients $^{\mathrm{a}}$

\begin{tabular}{|c|c|c|c|c|c|c|}
\hline & \multirow[t]{2}{*}{ Model } & \multicolumn{2}{|c|}{$\begin{array}{l}\text { Unstandardized } \\
\text { Coefficients }\end{array}$} & \multirow{2}{*}{$\begin{array}{c}\text { Standardized } \\
\text { Coefficients }\end{array}$} & \multirow[t]{2}{*}{$\mathrm{T}$} & \multirow[t]{2}{*}{ Sig. } \\
\hline & & B & Std. Error & & & \\
\hline & (Constant) & .796 & .318 & & 2.508 & .014 \\
\hline & Kualitas Layanan & .248 & .063 & .302 & 3.919 & .000 \\
\hline 1 & Kualitas Produk & .222 & .057 & .286 & 3.896 & .000 \\
\hline & Kepercayaan & .169 & .061 & .215 & 2.785 & .006 \\
\hline & Nilai_Nasabah & .228 & .063 & .267 & 3.634 & .000 \\
\hline
\end{tabular}

a. Dependent Variable: Kepuasan Nasabah

Berdasarkan pada tabel 4.16 tersebut disusun persamaan regresi sebagai berikut : $\mathrm{Y}=0.796+0.248 \mathrm{X} 1+0.222 \mathrm{X} 2+0.169 \mathrm{X} 3+0.228 \mathrm{X} 4$

Adapun Interpretasi dari persamaan tersebut adalah :

$\alpha=0,796$ artinya jika kualitas layanan, kualitas produk, kepercayaan, nilai nasabah tidak ada perubahan maka kepuasan nasabah adalah 0,796 satuan.

$\beta_{1}=0,248$ artinya setiap terjadi peningkatan kualitas layanan satu satuan maka akan terjadi kenaikan kepuasan nasabah sebesar 0,248 satuan jika variabel independen yang lain tetap.

$\beta_{2} \quad=0,222$ artinya setiap terjadi peningkatan kualitas produk satu satuan maka akan terjadi kenaikan kepuasan nasabah sebesar0,222 satuan jika variabel independen yang lain tetap.

$\beta_{3}=0,169$ artinya setiap terjadi perubahan kepercayaan satu satuan maka maka akan terjadi kenaikan kepuasan nasabah sebesar0,169 satuan jika variabel independen yang lain tetap.

$\beta_{4}=0,228$ artinya setiap terjadi peningkatan nilai nasabah satu satuan maka akan terjadi kenaikan kepuasan nasabah sebesar0,228 satuan jika variabel independen yang lain tetap.

\section{b. Pengujian Hipotesis}

1) Uji Determinasi $\left(R^{2}\right)$

Koefisien determinasi $\left(\mathrm{R}^{2}\right)$ bertujuan untuk mengukur seberapa jauh kemampuan model dalam menerangkan variabel dependen. Nilai koefisien determinasi adalah antara nol dan satu. Nilai $\mathrm{R}^{2}$ yang kecil berarti kemampuan variabel-variabel independen dalam menjelaskan variasi variabel dependen sangat terbatas.

Tabel 4.2 Adjusted $R^{2}$ Determinasi

\begin{tabular}{|l|c|r|r|r|}
\hline Model & $\mathrm{R}$ & R Square & Adjusted R Square & Std. Error of the Estimate \\
\hline 1 & $.739^{\mathrm{a}}$ & .546 & .527 & .27671 \\
\hline
\end{tabular}

a. Predictors: (Constant), Nilai_Nasabah, Kualitas Produk, Kualitas Layanan, Kepercayaan

$$
\text { KD } \quad=0,756 \times 100=75,6 \%
$$

Nilai Adjusted $R^{2}$ pada tabel 4.17 sebesar 0,527, hal ini berarti variabel kualitas pelayanan, kualitas produk, kepercayaan nasabah, nilai nasabah pada bank PD. BPR BKK Purbalingga Cabang Bukateja menentukan kepuasan nasabah sebesar $52,7 \%$ sedangkan sisanya $47,3 \%$ dipengaruhi oleh faktor lain yang tidak diteliti dalam penelitian ini.

2) Uji F

Dalam pengujian uji $\mathrm{F}$ bertujuan untuk menganalisis derajat signifikan hubungan variabel-variabel independen kualitas pelayanan, kualitas produk, 
kepercayaan dan nilai nasabah secara bersama-sama terhadap variabel kepuasan nasabah (Y) menggunakan uji F pada tabel sebagai berikut :

\section{Tabel 4.3 Hasil Uji F}

ANOVA $^{b}$

\begin{tabular}{|l|r|r|r|r|r|}
\hline \multicolumn{1}{|c|}{ Model } & $\begin{array}{c}\text { Sum of } \\
\text { Squares }\end{array}$ & Df & Mean Square & F & Sig. \\
\hline 1Regression & 9.016 & 4 & 2.254 & 29.436 & $.000^{\mathrm{a}}$ \\
Residual & 7.504 & 98 & .077 & & \\
Total & 16.520 & 102 & & & \\
\hline
\end{tabular}

a. Predictors: (Constant), nilai nasabah, kualitas produk, kualitas layanan, kepercayaan

b. Dependent: kepuasan nasabah

Hipotesis pertama : Kualitas Layanan, Kualitas Produk, Kepercayaan dan NilaiNasabahsecara simultan berpengaruh positif terhadap Kepuasan Nasabah.

Berdasarkan pengujian secara simultan dapat diketahui bahwa nilai $F_{\text {hitung }}$ sebesar 29,436 sedangkan nilai $F_{\text {tabel }}$ df (n-k-1) sebesar 2,46 dengan nilai signifikan 0,000. Karena nilai $F_{\text {hitung }}>F_{\text {tabel }}(29,436>2,46)$ maka Ho ditolak Ha diterima. Dengan demikian hipotesis pertama yang berbunyi Kualitas Layanan, Kualitas Produk, Kepercayaan dan Nilai Nasabahsecara simultan mempunyai pengaruh positif terhadap Kepuasan Nasabah dinyatakan diterima.

\section{3) Uji t}

a) Hipotesis kedua

Untuk menguji pengaruh kualitas layanan

secara parsial berpengaruh positif terhadap Kepuasan Nasabah yaitu dengan menggunakan uji t. Hasil uji t diketahui bahwa variabel kualitas layananmemiliki nilai $t_{\text {hitung }}$ sebesar 3,919 lebih besar dari nilai $t_{\text {tabel }}$ sebesar 1,984 dengan nilai signifikansi $<0,05$ yaitu 0,000 . Maka Ha diterima dan Ho ditolak,Dengan demikian hipotesis kedua yang berbunyi kualitas layananmempunyai pengaruh positif terhadap Kepuasan Nasabah dinyatakan diterima.

\section{b) Hipotesis ketiga}

Berdasarkan penghitungan uji t diketahui bahwa variabel Kualitas Produk memiliki nilai $t_{\text {hitung }}$ sebesar 3,896lebih kecil dari nilai $t_{\text {tabel }}$ sebesar 1,984 dengan nilai signifikansi < 0,05 yaitu 0,000.Maka Ha diterima dan Ho ditolak, dengan demikian hipotesis ketiga yang berbunyi Kualitas Produk mempunyai pengaruh positif terhadap Kepuasan Nasabah dinyatakan diterima.

\section{c) Hipotesis keempat}

Berdasarkan penghitungan uji t diketahui bahwa variabel kepercayaan nasabah memiliki nilai $t_{\text {hitung }}$ sebesar 2,785 lebih besar dari nilai $t_{\text {tabel }}$ sebesar 1,984 dengan nilai signifikansi < 0,05 yaitu 0,006. Maka Ha diterima dan Ho ditolak, dengan demikian hipotesis keempat yang berbunyi kepercayaan nasabah mempunyai pengaruh positif terhadap kepuasan nasabah dinyatakan diterima.

\section{d) Hipotesis keelima}

Berdasarkan penghitungan uji t diketahui bahwa variabel nilai nasabah memiliki nilai $t_{\text {hitung }}$ sebesar 3,634lebih besar dari nilai $t_{\text {tabel }}$ sebesar 1,984 
dengan nilai signifikansi $<0,05$ yaitu 0,000. Maka Ha diterima dan Ho ditolak, dengan demikian hipotesis kelima yang berbunyi nilai nasabah mempunyai pengaruh positif terhadap kepuasan nasabah dinyatakan diterima.

\section{c. Pembahasan}

1) Pengaruh Kualitas Layanan Terhadap Kepuasan Nasabah

Kualitas layanan berpengaruh positif terhadap kepuasan nasabah PD. BPR BKK Purbalingga Cabang Bukateja. Hal ini dapat dilihat dari hasil statistik uji $t$ memiliki nilai $t_{\text {hitung }}$ sebesar 3,919lebih kecil dari nilai $\mathrm{t}_{\text {tabel }} 1,984$ dengan nilai signifikan 0,000 lebih besar dari $\alpha(0,05)$.

2) Pengaruh Kualitas Produk Terhadap Kepuasan Nasabah

Kualitas produk berpengaruh positif dan signifikan terhadap kepuasan nasabah PD. BPR BKK Purbalingga Cabang Bukateja. Hal ini dapat dilihat dari hasil statistik uji $t$ memiliki nilai $t_{\text {hitung }}$ sebesar 3,896lebih besar dari nilai $t_{\text {tabel }}$ sebesar 1,984dengan nilai signifikan 0,000 lebih kecil dari $\alpha(0,05)$.

\section{3) Pengaruh Kepercayaan Nasabah Terhadap Kepuasan Nasabah}

Kepercayaan nasabah tidak berpengaruh terhadap kepuasan nasabah PD. BPR BKK Purbalingga Cabang Bukateja. Hal ini dapat dilihat dari hasil statistik uji t memiliki nilai $t_{\text {hitung }}$ sebesar 2,785 lebih kecil dari nilai $t_{\text {tabel }}$ sebesar 1,984 dengan nilai signifikan 0,006 lebih besar dari $\alpha(0,05)$.

4) Pengaruh Nilai Nasabah Terhadap Kepuasan Nasabah

Nilai nasabah berpengaruh positif dan signifikan terhadap kepuasan nasabah PD. BPR BKK Purbalingga Cabang Bukateja. Hal ini dapat dilihat berdasarkan hasil statistik uji $\mathrm{t}_{\text {hitung }}$ sebesar 3,634>t $\mathrm{t}_{\text {tabel }}$ sebesar 1,984dengan nilai signifikan 0,000 lebih kecil dari $\alpha(0,05)$.

\section{Kesimpulan dan Saran}

\section{Kesimpulan}

Berdasarkan analisis yang telah dilakukan, maka ditarik beberapa kesimpulan,antara lain :

a. Kualitas Pelayanan, Kualitas Produk, Kepercayaan, dan Nilai Nasabah secara simultan berpengaruh terhadap Kepuasan Nasabah hal ini dapat dilihat berdasarkan hasi statistik nilai $\mathrm{F}_{\text {hitung }}$ sebesar 29,436 > $\mathrm{F}_{\text {tabel }}$ sebesar 2,46 dengan nilai signifikan $0,000<0,05$.

b. Kualitas Layanan berpengaruh positif dan signifikan terhadap Kepuasan Nasabah, hal ini dapat dilihat dari hasil statistik uji t memiliki nilai $t_{\text {hitung }}$ sebesar 3,919 lebih besar dari nilai $t_{\text {tabel }}$ sebesar 1,984 dengan nilai signifikansi $<0,05$ yaitu 0,000 .

c. Kualitas Produkberpengaruh positif dan signifikan terhadap Kepuasan Nasabah. Hal ini dapat dilihat dari hasil statistik uji t memiliki nilai $t_{\text {hitung }}$ sebesar 3,896lebih besar dari nilai $t_{\text {tabel }}$ sebesar 1,984 dengan nilai signifikansi< 0,05 yaitu 0,000 .

d. Kepercayaanberpengaruh positif dan signifikan terhadap Kepuasan Nasabah. Hal ini dapat dilihat dari hasil statistik uji t memiliki nilai $t_{\text {hitung }}$ sebesar 2,785lebih besar dari nilai $t_{\text {tabel }}$ sebesar 1,984 dengan nilai signifikansi $<0,05$ yaitu 0,006 .

e. Nilai Nasabah berpengaruh positif dan signifikan terhadap Kepuasan Nasabah. Hal ini dapat dilihat dari hasil statistik uji t memiliki nilai $t_{\text {hitung }}$ sebesar 3,634 lebih besar dari nilai $t_{\text {tabel }}$ sebesar 1,984 dengan nilai signifikansi $<0,05$ yaitu 0,000 .

\section{Saran}

a. Bagi pihak Bank BPR BKK Purbalingga agar dapat lebih meningkatkan kepercayaandan nilai nasabah dengan memberikan hal-hal yang lebih menarik dan sesusai keinginan nasabah sehingga dapat meningkatkan kepuasan nasabah, dengan meningkatnya kepuasan nasabah sehingga secara tidak langsung dapat meningkatkan kesetiaan nasabah. 
b. Bagi pihak manajemen pemasaran dalam perbankan diharapkan dapat membangun hubungan lebih baik dengan konsumendengan cara melakukan pendekatanpendekatan contohnya lewat promosi yang ditawarkan tentang produk PD. BPR BKK Purbalingga Cabang Bukateja, mengetaui keinginnan dan harapan nasabah sebisa mungkin dapat menarik hati nasabah agar dapat menarik nasabah baru, semakin baik pendekatan yang dilakukan pihak manajemen pemasaran terhadap nasabah

c. Bagi peneliti yang ingin melakukan penelitian lebih lanjut tentang kepuasan nasabah pada PD. BPR BKK sebaiknya menambah atau merubah variabel yang ada sehingga dapat memperjelas pembentukan variabel kepuasan nasabah.

\section{DAFTAR PUSTAKA}

Aaker, David, A. 2008. Manajemen Ekuitas Merek: Memanfaatkan Nilai Dari Suatu Merek. Jakarta:Mitra Utama.

Adi Putra, I Wayan Jaman. 2011. Pengaruh Kualitas Pelayanan Terhadap Loyalitas Debitur Kredit Produktif (Studi pada Kantor Cabang BNI SKC Malang).

Ariani, D. Wahyu. 2009. Manajemen Operasi Jasa. Cetakan Pertama. Graha Ilmu. Yogyakarta.

Arikunto, Suharsimi. 2010. Prosedur Penelitian Suatu Pendekatan Praktik. Jakarta : Rineka Cipta.

Aryani, Dwi dan Rosinta, Febrina. 2010. Pengaruh Kualitas Layanan terhadap Kepuasan Pelanggan dalam Membentuk Loyalitas Pelanggan. Volume 17, Nomor 2

BPR BKK, 2015, (https://id.m.wikipedia.org/wiki/Bank_Perkreditan_Rakyat), (online) diunduh November 2015.

Data dari buku PD BPR BKK Purbalingga. 24 September 2015

Effendi, Sofian. 2012. Metode Penelitian Survei. LP3ES anggota Ikapi: Jakarta

Ferrinadewi, Erna \& S.Pantja Djati, 2004, "Upaya Mencapai Loyalitas Konsumendalam Perspektif Sumber Daya Manusia”, Jurnal Kewirausahaan danManajemen, Vol.6 No.1, pp.15-26

Gaffar, Vanessa. 2007. CRM dan MPR Hotel. Bandung: Alfabeta

Gilbert, G.R. et.al. 2004. Measuring Customer Satisfaction in TheFast Food Industry: A crossnational Approach. The Journal ofsevices Marketing, 18.

Gilaninia,Shahram, Mohammad Teleghani, and Mohammad Reza Khorshidi Talemi. The Impact of Service Quality on Customer Satisfaction.Journal of Research and Development, 1 (4), pp: $1-7$.

Ghozali, Imam. 2005, Analisis Multivariate dengan Program SPSS, Badan Penerbit Universitas Diponegoro, Semarang. (online)

2011. Aplikasi Analisis Multivariat dengan Program IBM SPSS 19. Semarang: Badan Penerbit Universitas Diponegoro.

2013. Aplikasi Analisis Multivariate Dengan Program. Edisi Ketujuh. Semarang: Badan Penerbit Universitas Diponegoro.

Hartono, Falochah. 2013 Analisis Pengaruh Kepercayaan Dan Kualitas Layanan Terhadap Loyalitas Pelanggan Dengan Kepuasan Konsumen Sebagai Variabel Mediasi (Studi Pada Rs Darul Istiqomah Kaliwungu Kendal).

Hermawan, Kartajaya. 2006. Hermawan Kartajaya on Marketing Mix Seri 9 Elemen Marketing. Bandung: PT. Mizan Pustaka.

Hidayat, Rachmad. 2009. Pengaruh Kualitas Layanan, Kualitas Produk dan Nilai Nasabah Terhadap Kepuasan dan Loyalitas nasabah Bank Mandiri. Jurnal Manajemen Pemasaran dan Kewirausahaan. Vol. 11, No. 1

Irawan , Handi. 2008, Sepuluh Prinsip Kepuasan Pelanggan, Penerbit Elex Media Komputindo Kelompok Gramedia Jakarta.

Kotler, Philip and Gary Amstrong. 2004, Manajemen Pemasaran, Edisi Milenium, Salemba Empat: Jakarta

\& Amstrong, G. (2006). Principle of marketing. Prentice Hall, Inc.

2007. Manajemen Pemasaran. Jakarta: PT Malanan Jaya Cemerlang Kotler, Philip dan Gary Armstrong, 2006. Prinsip-Prinsip Pemasaran. Jilid 1 dan 2. edisi Keduabelas. Jakarta: Erlangga. 
\& Amstrong, G. 2012. Principles of Marketing. 14th Edition. Perason Prentice Hall.

\& K. L. Keller 2008,Manajemen Pemasaran (Edisi Kedua Belas), Cetakan Ketiga, PT. Indeks, Jakarta.

\& K. L. Keller. 2009. Manajemen Pemasaran. Edisi 12. Jakarta: Indeks.

Kresnamurti, Agung \& Putri, Ariani. 2012. Pengaruh Kualitas Produk dan Citra Merek terhadap Loyalitas Konsumen pada Produk Oli Federal di Wilayah Jakarta Timur (Studi Kasus pada Bengkel Resmi AHASS 2657 Dewi Sartika). Jurnal Economic Sains, vol X, No 1

Mulyono, B.H, Y , N. Rini, \& Kamal, M. Analisis pengaruh kualitas produk dan kualitas layanan terhadap kepuasan konsumen (studi kasus pada perumahan puri mediterania Semarang). Jurnal studi manajemen \&organisasiVolume 4, Nomor 2, Juli, Tahun 2007, Halaman 91http://ejournal.undip.ac.id/index.php/smo.

Oliver, R.L., 2007. Response Determinants in Satisfaction Judgments, Journal of Consumer Research, Vol.14 (March), pp. 495-507. Academy of Marketing Science Review Volume 2000 No. 1 Available: http://www.amsreview.org/articles/giese01-2000. pdf Copyright (C) 2007 - Academy of Marketing Science.

Paliliati, Alida. 2007. Analisis Pengaruh Nilai Pelanggan, Kepuasan Terhadap Loyalitas Nasabah Tabungan Perbankan Di Sulawesi Selatan. Jurnal Manajemen dan Kewirausahaan, Vol.9, No. 1, pp. 73-81, Maret 2007.

Parasuraman, A., Zeithaml, V.A., and Berry, L.L., 2011, “A Copceptual Model of Service Quality and Its Implications for Future Research", Journal of Marketing, Vol 49, Fall, pp. 41-50

Sugiyono. 2013. Metode Penelitian Kombinasi (Mixed Methods). Bandung : Alfabeta.

Tjiptono, Fandy., 2007, Pemasaran Jasa, Malang: Banyumedia Publishing. ., 2008, Manajemen Jasa, Andi Offset, Yogyakarta

, 2011, Pemasaran Jasa, Malang: Banyumedia.

Tjiptono, Fandy. 2011. Service Quality \& Satisfaction. Edisi 3. Yogyakarta: ANDI.

Umar, Husein. 2008. Metode Riset Bisnis. PT. Gramedia Pustaka Utama: Jakarta

Wahjono. 2010. Manajemen Pemasaran Bank. Cetakan pertama. Graha Ilmu. Yogyakarta.

Waseso, Segero. Pengaruh Persepsi Kualitas Pelayanan Terhadap Kepuasan Dan Loyalitas Pelanggan, Vol. 13, (Jurnal ekonomi bisnis: Desember 2008), (Skripsi).

Wijaya, Tony. 2011. Manajemen Kualitas Jasa. PT Indeks Kembangan, Jakarta.

Wisnalmawati. 2005 Pengaruh Persepsi Dimensi Kualitas Layanan terhadap Niat Pembelian Ulang. Jurnal Ekonomi dan Bisnis. No. 3 Jilid 10 2005, h.153-165.

Yumit, Zulian, 2010. Manajemen Kualitas Produk dan Jasa, Ekonisia, Yogyakarta, (online). 